\title{
Geometrical and geotechnical characterization of the earth fissures appeared in the Guadalentín Valley (southeastern Spain) after the September 2012 flooding
}

\author{
José Luis Pastor ${ }^{1}$, Joaquín Mulas ${ }^{2}$, Roberto Tomás ${ }^{1}$, Gerardo Herrera ${ }^{2}$, José \\ Antonio Fernández-Merodo ${ }^{2}$, Marta Béjar-Pizarro ${ }^{2}$, Luis Jordá ${ }^{2}$, Juan Carlos García López-Davalillos ${ }^{2}$, \\ Ramón Aragón ${ }^{2}$, and Rosa María Mateos ${ }^{2}$ \\ ${ }^{1}$ Department of Civil Engineering. University of Alicante, P.O. Box 99, 03080 Alicante, Spain \\ ${ }^{2}$ Grupo de Riesgos Geológicos, Departamento de Investigación y Prospectiva Geo-científica, Instituto \\ Geológico y Minero de España (IGME), Ministerio de Economía y Competitividad, c/ Alenza 1, \\ 28003 Madrid, Spain
}

Correspondence: José Luis Pastor (joseluis.pastor@ua.es)

Published: 22 April 2020

\begin{abstract}
Two earth fissures appeared in Murcia province (southeastern Spain) after the flood occurred because of a heavy downpour on 28 September 2012. In this area, located within the Guadalentín Valley, up to $212 \mathrm{~L} \mathrm{~m}^{-2}$ was reported that day. More than 200 agricultural exploitations were destroyed by the flooding, with a devastating effect on many infrastructures, such as a main A-7 highway bridge that collapsed in this event. The earth fissures appeared after this flooding in the towns of Puerto Lumbreras and Totana. The first fissure showed a straight-line direction approximately parallel to the main geological structures of the Guadalentín Valley. The total length of the fissure was $400 \mathrm{~m}$ and was 2 to $3 \mathrm{~m}$ in depth. The soil in the fissure is classified as a low-plasticity silt with some sand and clay, ML, according to the Unified Soil Classification System. From the sieve and hydrometer tests, the percentage of silt in these samples was between $48 \%$ and $68 \%$, the clay content between $12 \%$ and $30 \%$ and the sand content between $2 \%$ and $40 \%$. The plasticity index was smaller than 9.2 for all the samples. To evaluate the piping and internal erosion susceptibility of the soil, pinhole, crumb and geochemical tests were done on the collected samples. A result of non-dispersive soil was obtained from crumb and pinhole tests. Nevertheless, the $\mathrm{pH}$, sodium adsorption ratio and exchangeable sodium percentage tests showed that some samples could be affected by the dispersion of the soil. Also, the collapsible potential of the soil was studied, showing negative results for all the samples except for that collected at the southern end of the fissure, which showed a medium to high potential. Concerning the Totana fissure, it appeared with different branches and holes instead of as a rectilinear pattern. The total length of the fissure was $190 \mathrm{~m}$, with the soil characterized as a silty soil. Lastly, INSAR data, GPS, GPR and land subsidence maps were used to study the possible origin of these fissures.
\end{abstract}

\section{Introduction}

Earth fissures are open-ground fractures that form in unconsolidated sediments as the result of tensional stresses applied in the ground. These fissures are usually associated with land subsidence due to water withdrawal (Arizona Geological Survey, 2019; Schumann and Poland, 1970). This kind of fissure associated with land subsidence has been reported in many places around the world, as in Arizona (USA) (Jachens and Holzer, 1982), Saudi Arabia (Bankher and Al-Harthi, 1999) or China (Zhang et al., 2008; Hu et al., 2019). In all these cases, the fissures appeared in arid and semi-arid lands.

The soil affected by the earth fissure in the Saudi Arabia case (Bankher and Al-Harthi, 1999) was a Quaternary alluvium soil classified as a low-plasticity silt. This soil showed some collapsibility potential. The geophysical investigation 


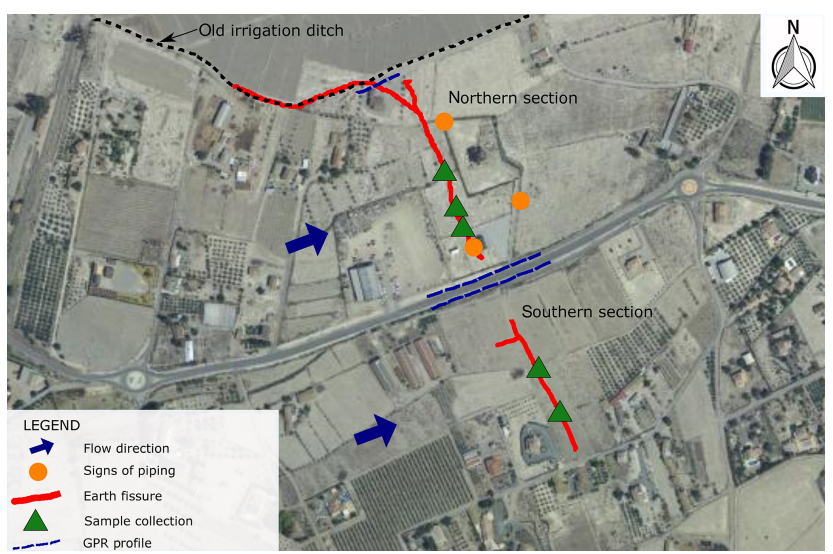

Figure 1. Location of the Puerto Lumbreras earth fissure and the locations of signs of piping and sample collection (modified from Mulas, 2013). Orthophoto from PNOA 2019 CC-BY scne.es.

done in this case indicated that the open-earth fissures were located above ridges and steps of the buried bedrock surface, where the aquifer alluvium thins. Moreover, the fissures were opened and enlarged by flood erosion. Regarding the case reported by Zhang et al. (2008) in China, the earth fissures affected Quaternary deposits of alluvial, lacustrine, marine and palustrine types, formed by clay, silty clay, silt, sand and gravel. In this case, the earth fissures mainly occurred in belts. These belts were formed by a main fissure, 3 to $6 \mathrm{~cm}$ in width, and several subordinates' fissures on both sides of the main one. An extensive area affected by subsidence was studied. Earth fissures were detected only in the zone where the bedrock tectonics is complex, including several folds and faults, and some buried scarps that change abruptly the thickness of the Quaternary deposits. In other zones of the study, such as Shanghai or Suzhou, the bedrock basement is deeper and changes smoothly. No earth fissures were detected on these zones, although the total subsidence was bigger here than in the other zones.

Also in the case reported by Jachens and Holzer (1982) in Arizona, all of the fissure zones occurred above either ridges or steps in the bedrock features. This seems to be a common pattern in subsidence areas where fissures have appeared.

In this study, the two earth fissures that developed after a flood event in the Guadalentín Valley (Murcia, southeastern Spain) have been both geometrically and geotechnically characterized. The purpose of this characterization was to know the soil properties where the cracks were open and to define the cracks' geometry. This information, together with that provided by future research, could help to understand the cause of the earth fissures that appeared after the flood.

The flooding was caused by an intense rainfall that lasted $3 \mathrm{~d}$ accumulating up to $212 \mathrm{~mm} \mathrm{~m}^{2}$. This event caused $10 \mathrm{fa}-$ talities ( 3 in the area near the Puerto Lumbreras fissure), destroyed more than 200 agricultural farms and had a catas-

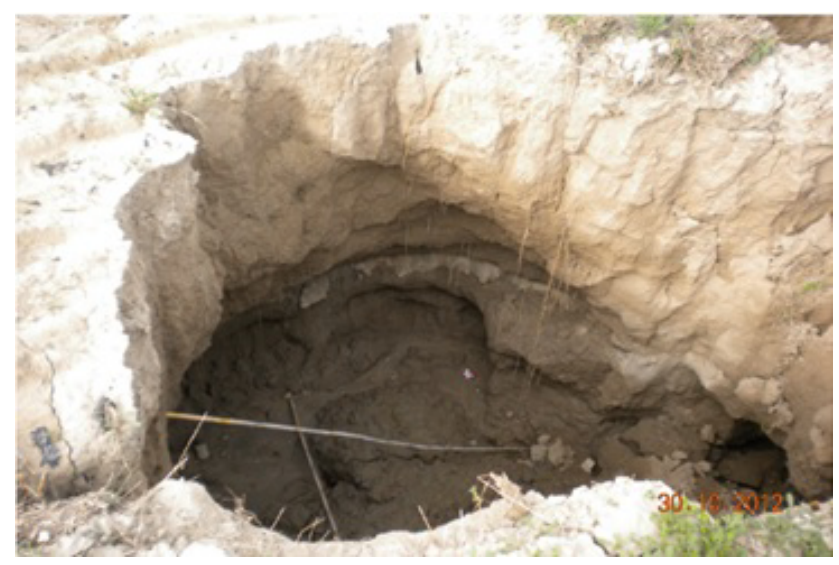

Figure 2. Signs of piping along the fissure. Soil erosion caused by water beneath the surface of the ground creating an underground tunnel.

trophic impact on many infrastructures, collapsing, amongst others, a main highway bridge.

\section{Materials and methods}

The geometrical and geotechnical characterization of both fissures was done in two stages: (1) mapping the fissures using a GPS in the field and (2) collecting soil samples from within the fissures to analyze them in the laboratory. In addition to mapping the fissure, a ground-penetrating radar (GPR) was used near both fissures to detect possible anomalies in the first meters of depth.

Regarding the laboratory tests performed to characterize the soil, five samples were collected in the Puerto Lumbreras fissure by the Geological Survey of Spain performing the following tests: (a) particle size distribution (sieve and hydrometer); (b) Atterberg limits; (c) free swell index; (d) collapsibility index; (e) pinhole, crumb and double hydrometer; (f) sulfate content; (g) sodium adsorption ratio; and (h) exchangeable sodium percentage.

In addition, one sample was collected to characterize the soil within the Totana fissure. Soil classification tests (sieve analysis, hydrometer and Atterberg limits) and soil dispersion tests (pinhole, crumb and double hydrometer) were performed on this sample.

\section{Results and discussion}

The mapping of the Puerto Lumbreras earth fissure is shown in Fig. 1, modified from Mulas (2013). This figure shows the distribution of the fissure that appeared when waters receded on a very flat land. The main crack was about $400 \mathrm{~m}$ long and was perpendicular to the main flow of the flood, except for the northern section of the crack where it was nearly parallel to the flow. The crack presented a main NW-SE orientation $(\mathrm{N} 150 \mathrm{E})$ that changes to $\mathrm{E}-\mathrm{W}$ in the northern section. 


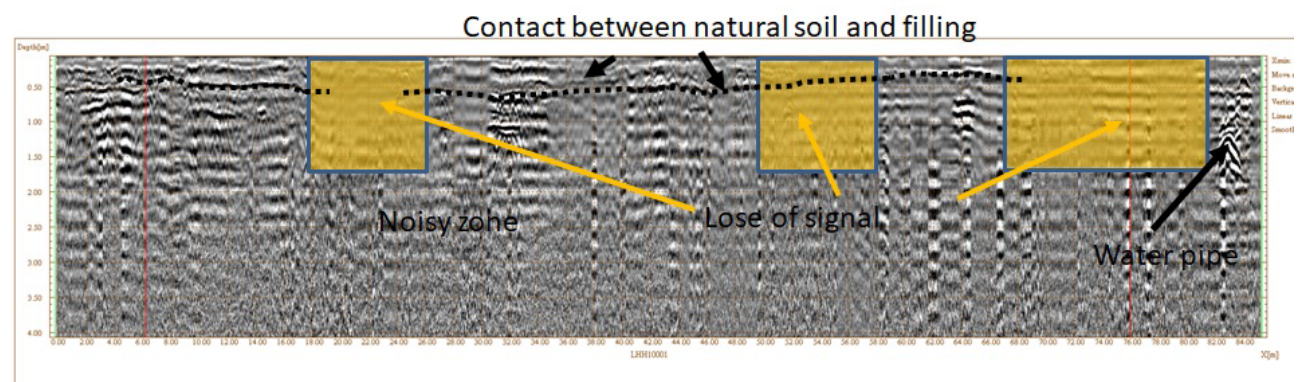

Figure 3. Ground-penetrating radar along the ditch beside the road.

It is important to point out that the continuity of the earth fissure was disrupted by the road located at the center of the figure, which presents a lower elevation. The orange points in Fig. 1 indicate those locations in which signs of piping were recognized in the field (Fig. 2), and the green triangles indicate the locations from which soil samples were collected to be tested later in the laboratory.

During the field inspection, a damaged ditch was observed beside the aforementioned road after the flooding. This road was approximately parallel to the main flow of the flood and some erosion was clearly observed below the ditch.

A GPR was used along the ditch beside the road to analyze what was beneath the concrete (Fig. 3). The contact between the natural soil and the filling is observed in this figure. A water pipe was also detected, as well as some loss of signal that can be due to soil erosion. However, no good information was obtained below 1.5 to $2.0 \mathrm{~m}$, probably due to the silty clay composition of the soil. Figure 4 shows an aerial view of the northern section of the crack and the runoff flow direction. Note how the fissure intersects and surrounds the building. Figure 5 shows the location in which the direction of the fissure changed from NE-SW to E-W. The aperture of the fissure can be seen in this figure. The fissure showed rough and vertical sides with a maximum depth of $3.7 \mathrm{~m}$ and a maximum aperture of $2.7 \mathrm{~m}$.

As said above, for the geotechnical characterization, five soil samples were collected along the Puerto Lumbreras fissure. These samples were collected at the surface of the ground at several points along the main crack. According to the particle size distribution, the samples had a silt content between $48 \%$ and $68 \%$, a clay content between $12 \%$ and $30 \%$ and a sand content between $2 \%$ and $40 \%$. In all the samples, the plasticity index was lower than 9.2. Therefore, the samples were classified as a low-plasticity silt (ML) according to the Unified Soil Classification System (USCS). The clay minerals of the soil were mainly of the illite type. The result of the tests showed that the soil was neither expansive nor collapsible, except for one of the five samples, which exhibited a medium to high collapsibility. The soil also showed a low content of sulfates, between $0.03 \%$ and $0.20 \%$. Regarding the dispersion tests, crumb, double-

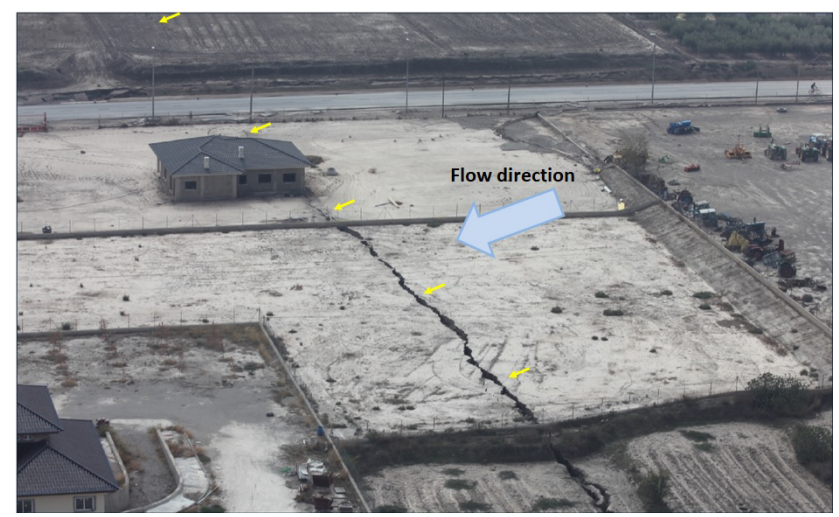

Figure 4. Aerial view of the northern section of the crack (courtesy of Puerto Lumbreras City Council). The yellow arrows indicate the location of the earth fissure (modified from Mulas, 2013).

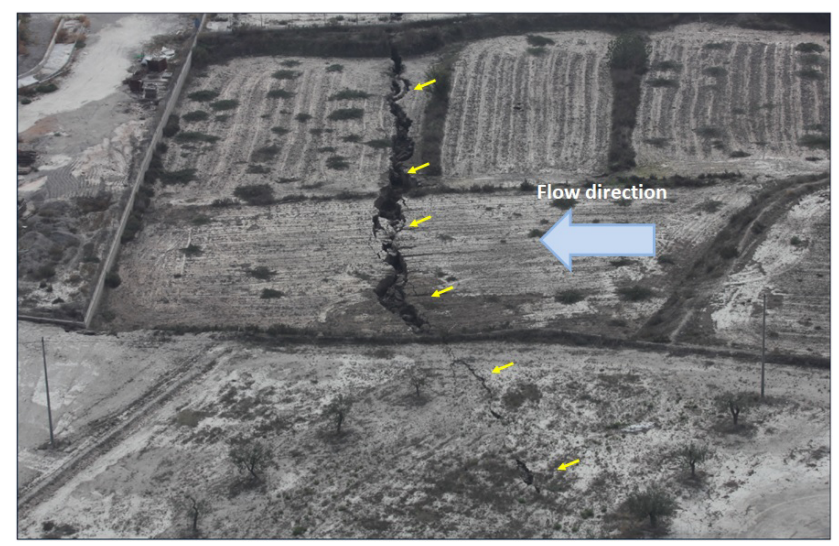

Figure 5. Aerial view of the third and second northern sections of the crack (courtesy of Puerto Lumbreras City Council). The yellow arrows indicate the location of the earth fissure (modified from $\mathrm{Mu}$ las, 2013).

hydrometer and pinhole tests showed a non-dispersive soil. Finally, the sodium absorption ratio obtained in the tests was between 0.8 and 8.8 and the exchangeable sodium percentage between $1.9 \%$ and $14.4 \%$. Therefore, these results show a non-dispersive soil for most of the samples, except for two 


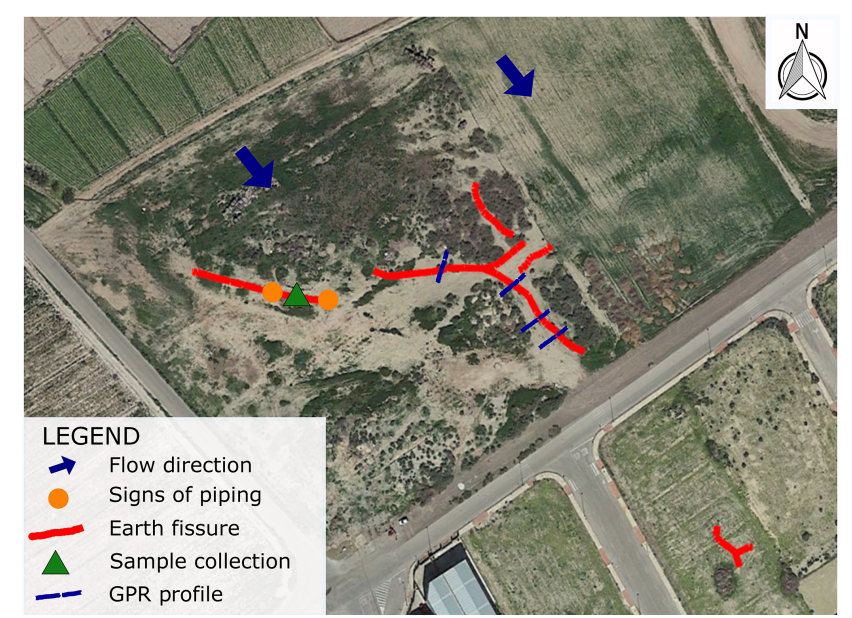

Figure 6. Location of the Totana earth fissure and the locations of signs of piping and sample collection. Orthophoto from PNOA 2019 CC-BY scne.es.

of them, which had a result of slightly to moderately dispersive soil. The non-dispersive results discard the clay particle dispersion into water and the later remobilization as the origin of the crack.

Regarding the Totana earth fissure, the location and distribution of the fissure observed when water receded can be seen in Fig. 6. Figure 7 shows a view of the fissured that appeared in Totana. The fissure appeared on a flat land and was discontinuous and ramified. Both soils, in Totana and Puerto Lumbreras, have a similar origin and a distal alluvial fan, although the age of the soils in Totana is older than in Puerto Lumbreras, Late or Upper Pleistocene (more than 10000 years ago) in Totana and Holocene (less than 10000 years ago) in Puerto Lumbreras. Some signs of piping were also observed in this fissure and one sample was collected at the site to test it later in the laboratory. The results of the tests show sand, silt and clay of $25 \%, 53 \%$ and $22 \%$, respectively. The liquid limit was 31.8 and the plasticity index 8.3. Therefore, the soil was classified as a low-plasticity silt (ML) according to the USCS. The results to assess the soil dispersion (crumb, double hydrometer and pinhole tests) showed a non-dispersive soil.

According to the hydrogeological scheme of the Guadalentín Valley (Cerón and Pulido-Bosch, 1996), the borders of the valley are formed by Perm-Triassic and Miocene materials. The basin filling is composed of gravels, clays and silts reaching up to $400 \mathrm{~m}$ thickness. The same authors performed a geoelectrical prospection to define the Plio-Quaternary thickness isolines and the main faults of the substratum. The cross section of the valley shown in that section indicated the existence of a graben structure. This kind of structure, where fault blocks are downthrown relative to their surroundings, can generate earth fissures due to differential land subsidence (Schumann and Poland, 1970; Zhang et al., 2008). Figure 8 shows an SAR interferometry deformation map derived from

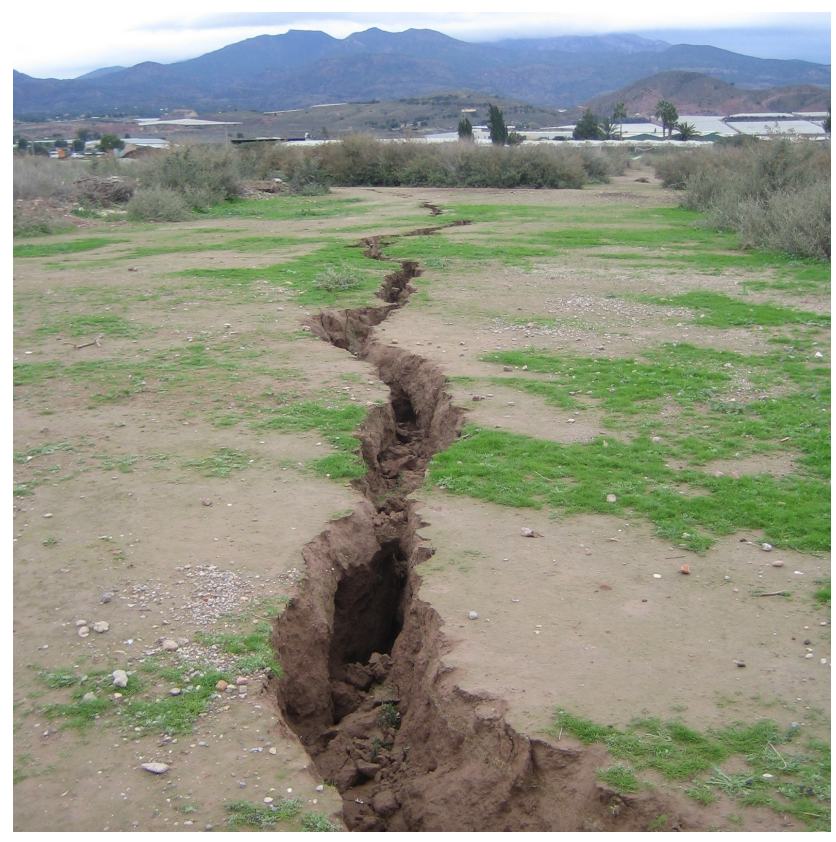

Figure 7. Image of the fissure that appeared in Totana.

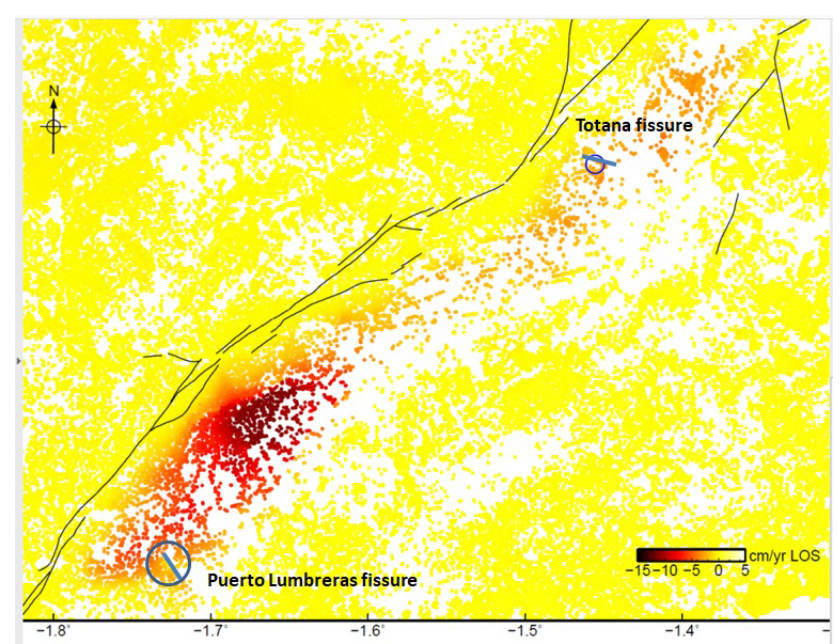

Figure 8. Locations of both fissures on the SAR interferometry deformation map of the Guadalentín Valley from Envisat 2003-2010. Continuous black lines represent surficial faults.

an Envisat dataset covering the period 2003-2010, where the location and main direction of the fissures have been drawn. As can be seen, both fissures are located near the edge of the subsidence bowl. It is worth pointing out that this valley presents the highest subsidence rate due to groundwater extraction in Europe, with accumulated settlements up to $2.5 \mathrm{~m}$ from 1992 to 2012 (Bonì et al., 2015).

The direction of one of the main geological structures of the Guadalentín Valley can be seen in Fig. 8. The other main direction is perpendicular to the first one (Cerón, 1997). Therefore, the directions of both fissures are approximately 
parallel to one of the directions of these main geological structures or faults in this area.

It should be mentioned that earth fissures reported in previous research due to subsidence have also appeared after highintensity rainstorms because of the flood erosion (Bankher and Al-Harthi, 1999; Schumann and Poland, 1970) and, thus, this could be the possible origin of the earth fissures studied in this work.

\section{Conclusions}

Two earth fissures were detected after a flood occurred because of a heavy downpour in the Guadalentín Valley. In both cases, the fissures appeared in a very flat area after waters receded. Signs of piping were observed along the fissures which affected low-plasticity silty soils. These soils showed low collapsibility potential in nearly all the tests and were classified as non-dispersive soils. The high subsidence rate of the area and the direction of the geological structures of the valley suggest that these fissures could be related to land subsidence. However, further studies are required to confirm this hypothesis.

Data availability. The geotechnical and InSAR data are available upon request by contacting the correspondence author.

Author contributions. JM, RT, GH, JAFM, MBP, JCGLD, RA and RMM performed different field surveys in the earth fissures. JLP, JM and RTJ collected soil samples. JLP and JM performed laboratory tests. LJ, JAFM, JM and RT performed the groundpenetrating radar survey. JLP wrote the draft version of the paper. All the authors analysed the data and revised the paper.

Competing interests. The authors declare that they have no conflict of interest.

Special issue statement. This article is part of the special issue "TISOLS: the Tenth International Symposium On Land Subsidence - living with subsidence". It is a result of the Tenth International Symposium on Land Subsidence, Delft, the Netherlands, 17-21 May 2021.

Financial support. This research has been supported by the Spanish Ministry of Economy and Competitiveness, the State Agency of Research and the European Funds for Regional Development (grant no. TEC2017-85244-C2-1-P), UNESCO (grant no. ICGP641), the Universidad de Alicante (grant no. GRE17-11), and the Universidad de Alicante (grant no. GRE18-15).

\section{References}

Arizona Geological Survey: Earth Fissures \& Ground Subsidence, AZGS, available at: https://azgs.arizona.edu/ center-natural-hazards/earth-fissures-ground-subsidence, last access: 22 August 2019.

Bankher, K. A. and Al-Harthi, A. A.: Earth Fissuring and Land Subsidence in Western Saudi Arabia, Nat. Hazards, 20, 21-42, https://doi.org/10.1023/A:1008167913575, 1999.

Bonì, R., Herrera, G., Meisina, C., Notti, D., Béjar-Pizarro, M., Zucca, F., González, P. J., Palano, M., Tomás, R., Fernández, J., Fernández-Merodo, J. A., Mulas, J., Aragón, R., Guardiola-Albert, C., and Mora, O.: Twenty-year advanced DInSAR analysis of severe land subsidence: The Alto Guadalentín Basin (Spain) case study, Eng. Geol., 198, 40-52, https://doi.org/10.1016/J.ENGGEO.2015.08.014, 2015.

Cerón, J. C.: Hidrogeoquímica del acuífero del alto Guadalentín (Murcia), edited by Consejería de Medio Ambiente Agricultura y Agua de la Región de Murcia, Murcia, Spain, 1997.

Cerón, J. C. and Pulido-Bosch, A.: Groundwater problems resulting from $\mathrm{CO}_{2}$ pollution and overexploitation in Alto Guadalentín aquifer (Murcia, Spain), Environ. Geol., 28, 223-228, https://doi.org/10.1007/s002540050096, 1996.

Hu, L., Dai, K., Xing, C., Li, Z., Tomás, R., Clark, B., Shi, X., Chen, M., Zhang, R., Qiu, Q., and Lu, Y.: Land subsidence in Beijing and its relationship with geological faults revealed by Sentinel1 InSAR observations, Int. J. Appl. Earth Observ. Geoinfo., 82, 101886, https://doi.org/10.1016/j.jag.2019.05.019, 2019.

Jachens, R. C. and Holzer, T. L.: Differential compaction mechanism for earth fissures near Casa Grande, Arizona, Geol. Soc. Am. Bull., 93, 998-1012, https://doi.org/10.1130/00167606(1982)93<998:DCMFEF>2.0.CO;2, 1982.

Mulas, J.: Las epectaculares grietas de Puerto Lumbreras, Enseñanza las Ciencias la Tierra, 21, 223-225, 2013.

Schumann, H. H. and Poland, J. F.: Land Subsidence, Earth Fissures and Groundwater Withdrawal in South-Central Arizona, U.S.A., in: Symposium on Land Subsidence, edited by: International Association of Scientific Hydrology, IASH/AIHS - Unesco, Tokyo, 1970.

Zhang, Y., Xue, Y.-Q., Wu, J.-C., Yu, J., Wei, Z.-X., and Li, Q.F.: Land subsidence and earth fissures due to groundwater withdrawal in the Southern Yangtse Delta, China, Environ. Geol., 55, 751-762, https://doi.org/10.1007/s00254-007-1028-8, 2008. 